\title{
Dual nitrogen and oxygen isotope fractionation during anaerobic ammonium oxidation by anammox bacteria
}

\author{
Kanae Kobayashi ${ }^{1} \cdot$ Akiko Makabe $^{2} \cdot$ Midori Yano $^{3} \cdot$ Mamoru Oshiki $^{4} \cdot$ Tomonori Kindaichi $^{5} \cdot$ Karen L. Casciotti $^{6}$. \\ Satoshi Okabe ${ }^{1}$
}

Received: 20 December 2018 / Revised: 21 March 2019 / Accepted: 16 April 2019 / Published online: 28 May 2019

(c) International Society for Microbial Ecology 2019

\begin{abstract}
Natural abundance of stable nitrogen $(\mathrm{N})$ and oxygen $(\mathrm{O})$ isotopes are invaluable biogeochemical tracers for assessing the $\mathrm{N}$ transformations in the environment. To fully exploit these tracers, the $\mathrm{N}$ and $\mathrm{O}$ isotope effects $\left({ }^{15} \varepsilon\right.$ and $\left.{ }^{18} \varepsilon\right)$ associated with the respective nitrogen transformation processes must be known. However, the $\mathrm{N}$ and $\mathrm{O}$ isotope effects of anaerobic ammonium oxidation (anammox), one of the major fixed $\mathrm{N}$ sinks and $\mathrm{NO}_{3}{ }^{-}$producers, are not well known. Here, we report the dual N and O isotope effects associated with anammox by three different anammox bacteria including "Ca. Scalindua japonica", a putative marine species, which were measured in continuous enrichment culture experiments. All three anammox species yielded similar $\mathrm{N}$ isotope effects of $\mathrm{NH}_{4}{ }^{+}$oxidation to $\mathrm{N}_{2}\left({ }^{15} \varepsilon_{\mathrm{NH} 4 \rightarrow \mathrm{N} 2}\right)$ ranging from $30.9 \%$ o to $32.7 \%$ o and inverse kinetic isotope effects of $\mathrm{NO}_{2}{ }^{-}$oxidation to $\mathrm{NO}_{3}{ }^{-}\left({ }^{15} \varepsilon_{\mathrm{NO} 2 \rightarrow \mathrm{NO} 3}=-45.3 \%\right.$ to $-30.1 \%$ ) $)$. In contrast, ${ }^{15} \varepsilon_{\mathrm{NO} 2 \rightarrow \mathrm{N} 2}$ $\left(\mathrm{NO}_{2}{ }^{-}\right.$reduction to $\left.\mathrm{N}_{2}\right)$ were significantly different among three species, which is probably because individual anammox bacteria species might possess different types of nitrite reductase. We also report the combined $\mathrm{O}$ isotope effects for $\mathrm{NO}_{2}{ }^{-}$ oxidation $\left({ }^{18} \mathrm{E}_{\mathrm{NO} 2 \rightarrow \mathrm{NO} 3}\right)$ by anammox bacteria. These obtained dual $\mathrm{N}$ and $\mathrm{O}$ isotopic effects could provide significant insights into the contribution of anammox bacteria to the fixed $\mathrm{N}$ loss and $\mathrm{NO}_{2}{ }^{-}$reoxidation ( $\mathrm{N}$ recycling) in various natural environments.
\end{abstract}

Supplementary information The online version of this article (https:// doi.org/10.1038/s41396-019-0440-x) contains supplementary material, which is available to authorized users.

Satoshi Okabe

sokabe@eng.hokudai.ac.jp

1 Division of Environmental Engineering, Faculty of Engineering, Hokkaido University, Sapporo, Hokkaido 060-8628, Japan

2 Japan Agency for Marine-Earth Science and Technology (JAMSTEC), Yokosuka 237-0061, Japan

3 Center for Ecological Research, Kyoto University, Otsu, Shiga 520-2113, Japan

4 Department of Civil Engineering, National Institute of Technology, Nagaoka College, Nagaoka, Niigata 940-8532, Japan

5 Department of Civil and Environmental Engineering, Graduate School of Engineering, Hiroshima University, Kagamiyama, Higashihiroshima 739-8511, Japan

6 Department of Earth System Science, Stanford University, Stanford, CA 94305, USA

\section{Introduction}

Both nitrogen $(\mathrm{N})$ and oxygen $(\mathrm{O})$ isotopes of fixed nitrogen compounds (i.e., ammonia, nitrite, and nitrate) are fractionated during their microbial production and consumption processes comprising the global marine $\mathrm{N}$ cycle. Thus, measurements of nitrogen $\left({ }^{15} \mathrm{~N} /{ }^{14} \mathrm{~N}\right)$ and oxygen $\left({ }^{18} \mathrm{O} /{ }^{16} \mathrm{O}\right)$ isotope ratios of fixed nitrogen compounds have long been used as invaluable biogeochemical stable isotopic tracers to estimate the global marine $\mathrm{N}$ budget $[1,2]$. The dual $\mathrm{N}$ and $\mathrm{O}$ isotope analyses provide complementary signatures of co-occurring $\mathrm{N}$ transformation processes that could not be revealed by $\mathrm{N}$ isotope measurement alone [3]. By convention, these stable isotope ratios are expressed in delta notation $\left(\delta^{15} \mathrm{~N}\right.$ and $\left.\delta^{18} \mathrm{O}\right)$ in per mille (\%o) versus atmospheric $\mathrm{N}_{2}$ (air) and Vienna Standard Mean Ocean Water (VSMOW): $\delta^{15} \mathrm{~N}=$ $\left(\left[{ }^{15} \mathrm{~N} /{ }^{14} \mathrm{~N}\right]_{\text {sample }} /\left[{ }^{15} \mathrm{~N} /{ }^{14} \mathrm{~N}\right]_{\text {air }}-1\right) \times 1000$ and $\quad \delta^{18} \mathrm{O}=$ $\left(\left[{ }^{18} \mathrm{O} /{ }^{16} \mathrm{O}\right]_{\text {sample }} /\left[{ }^{18} \mathrm{O} /{ }^{16} \mathrm{O}\right]_{\text {VSMOw }}-1\right) \times 1000$, respectively. To quantitatively assess the impacts of these processes on dissolved nitrogen species, the degree of isotope fractionation is quantified by the kinetic isotope effect, $\varepsilon(\% o)=\left[\left(k_{\mathrm{L}} /\right.\right.$ $\left.\left.k_{\mathrm{H}}\right)-1\right] \times 1000$, where $k_{\mathrm{L}} / k_{\mathrm{H}}$ is the ratio of the reaction 


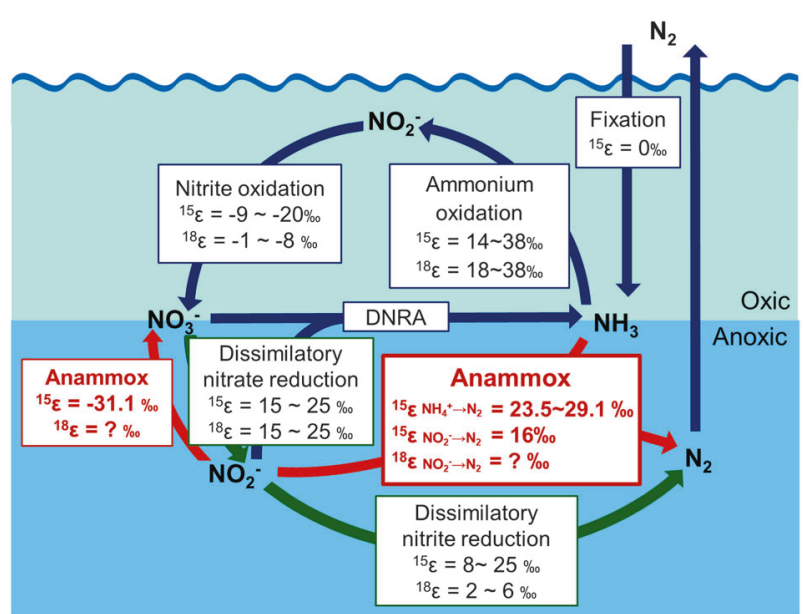

Fig. 1 Marine microbial nitrogen cycle with the reported $\mathrm{N}$ and $\mathrm{O}$ isotope effects $\left({ }^{15} \varepsilon\right.$ and ${ }^{18} \varepsilon$, respectively) of key transformation processes. The $\mathrm{O}$ isotope effects of anammox have not been determined yet

rate constants between the light $\left(k_{\mathrm{L}}\right)$ and heavy $\left(k_{\mathrm{H}}\right)$ isotopically substituted substrates. The kinetic $\mathrm{N}$ and $\mathrm{O}$ isotope effects $\left({ }^{15} \varepsilon\right.$ and ${ }^{18} \varepsilon$, respectively) for key microbial processes provide the basis for interpretation of natural abundance $\mathrm{N}$ isotopic distributions in the ocean, freshwater, terrestrial, and groundwater ecosystems.

The kinetic $\mathrm{N}$ and $\mathrm{O}$ isotope effects associated with microbial ammonium oxidation [4-8], nitrite oxidation $[9,10]$, dissimilatory nitrite reduction to nitric oxide [11], dissimilatory nitrate reduction (denitrification) [12, 13], and assimilatory nitrate reduction $[14,15]$ have been determined for laboratory cultures of corresponding bacteria (Fig. 1). These isotope effects vary depending on the microbial species [12], enzymes [11], growth conditions, and/or rates of reaction [6]. Furthermore, the coupled $\mathrm{N}$ and $\mathrm{O}$ isotope measurements of $\mathrm{NO}_{x}$ (nitrate and/or nitrite) have been performed in the North Pacific margin (e.g. [16-18]), Hadal oceans [19], and the Peru oxygendeficient zone (ODZ) [20-22] to assess the regional $\mathrm{N}$ cycles. However, there is still much uncertainty with regard to the $\mathrm{N}$ cycling processes, especially in ODZs because the isotope effects are not well known for all of the relevant processes.

Anaerobic ammonium oxidation (anammox) and denitrification are the two major sinks of fixed nitrogen $(\mathrm{N})$ in the ocean. It has been estimated that these microbial processes together remove $230-450 \mathrm{Tg} \mathrm{N} \mathrm{yr}^{-1}$ from the global ocean $[23,24]$, which is thought to occur mainly in oxygendeficient water columns and sediments. Furthermore, anammox bacteria also contribute to re-oxidation of nitrite to nitrate (i.e., recycling $\mathrm{N}$ ), because they fix $\mathrm{CO}_{2}$ into biomass with reducing equivalents generated from oxidation of nitrite to nitrate [25]. Nitrate production by anammox bacteria significantly influences the nitrite and nitrate $\mathrm{N}$ and $\mathrm{O}$ isotope effects in freshwater and marine systems, which, however, has been overlooked so far [26]. Despite the importance of anammox bacteria in the global $\mathrm{N}$ cycle [27-31], the $\mathrm{N}$ isotope effect $\left({ }^{15} \varepsilon\right)$ associated with anammox metabolism has been determined for only one freshwater anammox strain, "Ca. Kuenenia stuttgartiensis" [32]. The kinetic $\mathrm{O}$ isotope effect $\left({ }^{18} \varepsilon\right)$ of anammox metabolism has not yet been determined. Consequently, their impacts on the distributions of $\mathrm{N}$ and $\mathrm{O}$ isotopes in the natural environmets could not be addressed.

Five candidatus genera, 'Ca. Brocadia' [33], ' $\mathrm{Ca}$. Kuenenia' [34], 'Ca. Scalindua' [35], 'Ca. Anammoxoglobus' [36] and 'Ca. Jettenia' [37], and about 20 candidatus species have been tentatively identified to date. The genus ' $\mathrm{Ca}$. Scalindua' is halotolerant and the most abundant anammox bacteria found in marine environments [38]. We therefore hypothesized that the nitrite and nitrate $\mathrm{N}$ and $\mathrm{O}$ isotope effects induced by different genera of anammox bacteria might be different, since they are phylogenetically diverse and might possess different enzymes (e.g., nitrite reductase) and consequently different metabolic pathways [39]. Especially, the determination of isotope effects of marine anammox species, ' $\mathrm{Ca}$. Scalindua', is essential to better understand the natural abundance of stable isotope ratios $\left(\delta^{18} \mathrm{O}\right.$ and $\left.\delta^{15} \mathrm{~N}\right)$ in the ocean.

Here, we analyzed the $\mathrm{N}$ and $\mathrm{O}$ isotope effects $\left({ }^{15} \varepsilon\right.$ and ${ }^{18} \varepsilon$ ) of nitrite and nitrate associated with anammox metabolism by three anammox species: 'Ca. S. japonica', 'Ca. $J$. caeni', and ' $\mathrm{Ca}$. B. sinica' in continuous enrichment cultures. We found that species-dependent $\mathrm{N}$ and $\mathrm{O}$ isotope effects $\left({ }^{15} \varepsilon\right.$ and ${ }^{18} \varepsilon$ ), which could provide significant insights into the relative contribution of anammox bacteria to the fixed $\mathrm{N}$ loss and nitrite re-oxidation (recycling $\mathrm{N}$ ) in various natural environments.

\section{Materials and methods}

\section{Continuous culture experiments}

Free-living planktonic cultures of three anammox bacteria species were enriched and cultivated in $3 \mathrm{~L}$ membrane bioreactors (MBRs) equipped with a hollow fiber membrane module (pore size $0.1 \mu \mathrm{m}$, polyethylene) as previously described [38, 40, 41] (Fig. S1). The $\mathrm{pH}$ was not controlled but was always between 7.9-8.0 for " $\mathrm{Ca}$. S. japonica", 8.6-8.9 for "Ca. J. caeni”, and 7.3-7.4 for "Ca. B. sinica", respectively. The temperature was controlled at $25^{\circ} \mathrm{C}$ for "Ca. S. japonica", $30^{\circ} \mathrm{C}$ for "Ca. J. caeni", and $37^{\circ} \mathrm{C}$ for "Ca. B. sinica", respectively. The details of reactor operation and culture preparation are given in Fig. S1. Once the 
MBRs have reached a steady state (the concentrations of nitrogen compounds $\left(\mathrm{NH}_{4}^{+}, \mathrm{NO}_{2}^{-}\right.$, and $\left.\mathrm{NO}_{3}{ }^{-}\right)$in the effluents stabilized after about 2-month operation), three or four sub-samples of MBR influent and effluent (permeate) were taken. After sampling, $\mathrm{pH}$ was measured and immediately filtered using $0.2-\mu \mathrm{m}$ cellulose acetate filter (Advantec) for concentration and isotopic measurements of $\mathrm{NH}_{4}{ }^{+}, \mathrm{NO}_{2}^{-}$, and $\mathrm{NO}_{3}^{-}$.

\section{Sample preparation for isotopic analysis}

After filtration, immediately samples were adjusted to $\mathrm{pH} 2$ by adding $2 \mathrm{M} \mathrm{H}_{2} \mathrm{SO}_{4}$ solution and then stored at $-20^{\circ} \mathrm{C}$ until analysis for $\mathrm{N}$ isotope of $\mathrm{NH}_{4}{ }^{+}$to prevent $\mathrm{NH}_{4}{ }^{+}$from volatilizing. To analyze $\mathrm{N}$ and $\mathrm{O}$ isotope of $\mathrm{NO}_{2}{ }^{-}$, after filtration, immediately sample solution was adjusted to $\mathrm{pH} 12$ by adding $2 \mathrm{M} \mathrm{NaOH}$ solution and stored at $-20^{\circ} \mathrm{C}$ until analysis to prevent $\mathrm{O}$ isotope exchange between $\mathrm{NO}_{2}{ }^{-}$and $\mathrm{H}_{2} \mathrm{O}$ during sample storage. To analyze $\mathrm{N}$ and $\mathrm{O}$ isotope of $\mathrm{NO}_{3}{ }^{-}$, after filtration, if the concentration ratio of $\mathrm{NO}_{2}{ }^{-} / \mathrm{NO}_{3}{ }^{-}$ was over $5 \%, \mathrm{NO}_{2}{ }^{-}$in the sample solution was immediately removed by adding sulfamic acid $\left(\mathrm{H}_{3} \mathrm{NSO}_{3}\right)$, because $\mathrm{NO}_{2}{ }^{-}$ interferes with $\mathrm{NO}_{3}{ }^{-}$isotope analysis. The concentration of $\mathrm{NO}_{2}^{-}$was measured with naphthylethylenediamine method [42] to confirm $\mathrm{NO}_{2}^{-}$was completely removed. We confirmed that $\mathrm{NO}_{2}^{-}$was completely removed in all samples. Then, sample solution was adjusted to $\mathrm{pH} 8.5-9$ by adding $2 \mathrm{M} \mathrm{NaOH}$ solution and stored at $-20^{\circ} \mathrm{C}$ until analysis.

\section{Chemical analyses}

The concentration of $\mathrm{NH}_{4}{ }^{+}$was measured by the indophenol blue method [42] with a multi-label plate reader (ARVO MX 1420-01J; PerkinElmer; Waltham, MA, USA). The $\mathrm{NO}_{2}{ }^{-}$concentration was measured by the naphthylethylenediamine method [42]. The concentration of $\mathrm{NO}_{3}{ }^{-}$was measured using ion chromatographs (IC-2010, TOSOH; Tokyo, Japan) equipped with a TSKgel IC-Anion HS column (TOSOH; Tokyo, Japan).

\section{Isotope ratio analyses}

$\mathrm{NH}_{4}{ }^{+}$nitrogen isotope analyses were performed by using the ammonium diffusion method [43, 44] and subsequently measured by a EA-IRMS (Flash EA1112, ConFlo IV interface, Delta plus Advantage; ThremoFinnigan). International and internal $\mathrm{NH}_{4}{ }^{+}$isotopic standards, USGS25 $\left(\delta^{15} \mathrm{~N}=\right.$ $-30.4 \% o)$, USGS26 $\left(\delta^{15} \mathrm{~N}=53.7 \%\right)$, and IAEA-N-2 $\left(\delta^{15} \mathrm{~N}=20.3 \%\right.$ ) were used for the calibration. Replicate analyses yielded respective precision of $0.3 \%$ of $\delta^{15} \mathrm{~N}_{\mathrm{NH} 4+}$.

$\mathrm{NO}_{2}{ }^{-}$nitrogen and oxygen isotope ratios were measured by chemical conversion of $\mathrm{NO}_{2}{ }^{-}$to nitrous oxide $\left(\mathrm{N}_{2} \mathrm{O}\right)$ with the azide method [45]. All samples and standards were exactly adjusted to same $\mathrm{pH}(\mathrm{pH}=12)$ and salinity $(0.5 \mathrm{M}$ $\mathrm{NaCl}$ ) as mentioned above. The $\mathrm{N}_{2} \mathrm{O}$ was then analyzed in duplicate using a GC-IRMS (SerCon) with in-house calibrated $\mathrm{NO}_{2}{ }^{-}$isotopic standards that were calibrated against $\mathrm{N}-23, \mathrm{~N}-7373$, and $\mathrm{N}-10219$ [46]; NO2-1 $\left(\delta^{15} \mathrm{~N}=-66.9 \%\right.$, $\delta^{18} \mathrm{O}=27.0 \%$ o $), \quad \mathrm{NO} 2-2 \quad\left(\delta^{15} \mathrm{~N}=-64.8 \% o, \quad \delta^{18} \mathrm{O}=1.1 \% \circ\right)$, NO2-3 $\quad\left(\delta^{15} \mathrm{~N}=-67.3 \%, \quad \delta^{18} \mathrm{O}=20.3 \%\right), \quad \mathrm{NO} 2-4$ $\left(\delta^{15} \mathrm{~N}=-68.4 \%\right.$ o, $\left.\delta^{18} \mathrm{O}=14.9 \%\right), \quad \mathrm{NO} 2-5 \quad\left(\delta^{15} \mathrm{~N}=0.2 \%\right.$ ， $\delta^{18} \mathrm{O}=20.2 \%$ o). Replicate analyses yielded respective precisions of $0.3 \%$ for $\delta^{15} \mathrm{~N}_{\mathrm{NO} 2-}$ and $0.5 \%$ for $\delta^{18} \mathrm{O}_{\mathrm{NO} 2-}$, respectively.

$\mathrm{NO}_{3}{ }^{-}$nitrogen and oxygen isotope ratios were measured by microbial conversion of $\mathrm{NO}_{3}{ }^{-}$to $\mathrm{N}_{2} \mathrm{O}$ with the denitrifier method [47, 48]. $\mathrm{N}_{2} \mathrm{O}$ was analyzed in triplicate using a GC-IRMS (SerCon) with international $\mathrm{NO}_{3}{ }^{-}$isotopic standards; IAEAN3 $\left(\delta^{15} \mathrm{~N}=4.7 \% \%, \quad \delta^{18} \mathrm{O}=25.6 \% \circ\right)$, USGS32 $\left(\delta^{15} \mathrm{~N}=180 \%\right.$, $\left.\delta^{18} \mathrm{O}=25.7 \%\right)$, USGS34 $\left(\delta^{15} \mathrm{~N}\right.$ $\left.=-1.8 \% o, \quad \delta^{18} \mathrm{O}=-27.9 \% \circ\right), \quad$ and USGS35 $\quad\left(\delta^{18} \mathrm{O}=\right.$ $57.5 \%$ o). Replicate analyses yielded respective precisions of $0.2 \%$ or for $\delta^{15} \mathrm{~N}_{\mathrm{NO} 3-}$ and $1.0 \%$ or for $\delta^{18} \mathrm{O}_{\mathrm{NO} 3-}$, respectively.

\section{Calculations of isotope effects}

Anammox bacteria oxidize $\mathrm{NH}_{4}^{+}$directly to $\mathrm{N}_{2}$ gas with $\mathrm{NO}_{2}{ }^{-}$as the terminal electron acceptor in the absence of oxygen, and $\mathrm{NO}_{2}{ }^{-}$is concomitantly oxidized to $\mathrm{NO}_{3}{ }^{-}$as shown in the following stoichiometric equation [49]:

$$
\begin{gathered}
1 \mathrm{NH}_{4}^{+}+1.146 \mathrm{NO}_{2}^{-}+0.071 \mathrm{HCO}_{3}^{-}+0.057 \mathrm{H}^{+} \\
\rightarrow 0.986 \mathrm{~N}_{2}+0.161 \mathrm{NO}_{3}^{-}+0.071 \mathrm{CH}_{1.74} \mathrm{O}_{0.31} \mathrm{~N}_{0.20}+2.002 \mathrm{H}_{2} \mathrm{O}
\end{gathered}
$$

The continuous MBR system is considered as an open system with balanced input and two or three output fluxes (product(s) and residual substrate) [50]. The $\mathrm{N}$ isotope effects were analyzed for the following redox reaction: (1) $\mathrm{NH}_{4}{ }^{+}$oxidation to $\mathrm{N}_{2}$, (2) $\mathrm{NO}_{2}{ }^{-}$reduction to $\mathrm{N}_{2}$, and (3) $\mathrm{NO}_{2}{ }^{-}$oxidation to $\mathrm{NO}_{3}{ }^{-}$.

\section{$\mathrm{N}$ isotope effect of $\mathrm{NH}_{4}{ }^{+}$oxidation to $\mathrm{N}_{2}$}

Ammonium $\left(\mathrm{NH}_{4}{ }^{+}\right)$was continuously fed into the MBR where $\mathrm{NH}_{4}^{+}$oxidation to $\mathrm{N}_{2}\left(\mathrm{NH}_{4}{ }^{+} \rightarrow \mathrm{N}_{2}\right)$ occurs with fractionation $\left({ }^{15} \varepsilon_{1}\right)$, and unused $\mathrm{NH}_{4}{ }^{+}$exits without further fractionation (i.e., ${ }^{15} \varepsilon_{2}=0$ ) (Fig. 2a). The isotope compositions of product $\mathrm{N}_{2}\left(\delta_{\text {product }}\right)$ and residual $\mathrm{NH}_{4}{ }^{+}\left(\delta_{\mathrm{RS}}\right)$ at steady state can be given simply by subtracting $\varepsilon$ fractionations from the isotope composition of intermediate pool $\left(\delta_{\mathrm{p}}\right)[50]$.

$$
\begin{aligned}
& \delta_{\text {product }}=\delta_{\mathrm{p}}-{ }^{15} \varepsilon_{1} \\
& \delta_{\mathrm{RS}}=\delta_{\mathrm{p}}-{ }^{15} \varepsilon_{2}=\delta_{\mathrm{p}} \quad\left(\text { when }{ }^{15} \varepsilon_{2}=0\right)
\end{aligned}
$$




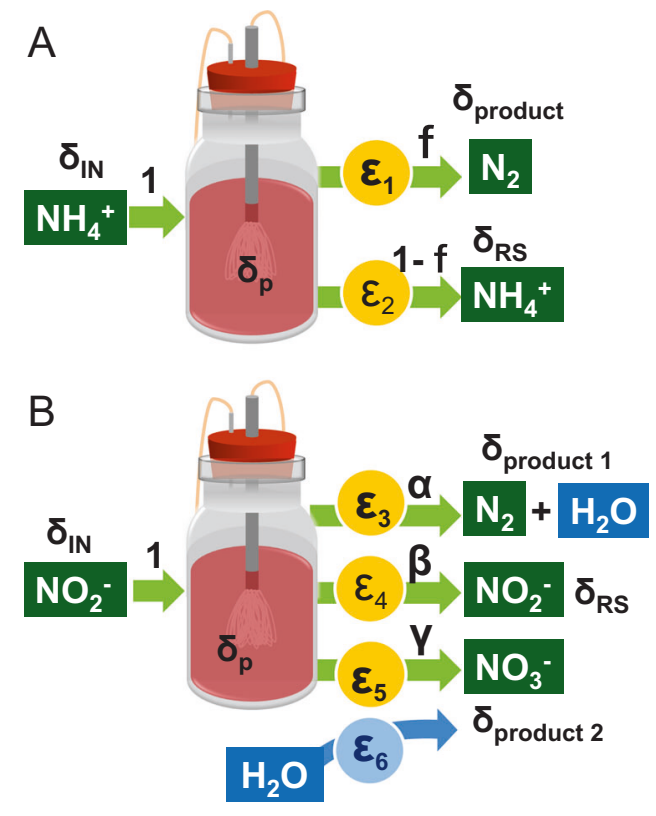

Fig. 2 Diagram of a steady-state box model. a a substrate $\left(\mathrm{NH}_{4}{ }^{+}\right)$ entering to a MBR and a product $\left(\mathrm{N}_{2}\right)$ is formed and unused substrate $\left(\mathrm{NH}_{4}{ }^{+}\right)$exits without further fractionation. b A substrate $\left(\mathrm{NO}_{2}{ }^{-}\right)$ entering to a MBR and two products $\left(\mathrm{N}_{2}\right.$ and $\left.\mathrm{NO}_{3}{ }^{-}\right)$are formed and unused substrate $\left(\mathrm{NO}_{2}^{-}\right)$exits without further fractionation

The steady-state isotope mass balance can be described as follows:

$$
\begin{gathered}
\delta_{\mathrm{IN}}=f \delta_{\text {product }}+(1-f) \delta_{\mathrm{RS}} \\
\delta_{\mathrm{IN}}=f\left(\delta_{\mathrm{p}}-{ }^{15} \varepsilon_{1}\right)+(1-f)\left(\delta_{\mathrm{p}}-{ }^{15} \varepsilon_{2}\right) \\
\delta_{\mathrm{p}}=\delta_{\mathrm{IN}}+f^{15} \varepsilon_{1}
\end{gathered}
$$

where $f$ is the fraction of $\mathrm{NH}_{4}{ }^{+}$consumed at steady state.

Therefore, from Eqs. (2) and (3), the kinetic isotope effects associated with $\mathrm{NH}_{4}{ }^{+}$oxidation to $\mathrm{N}_{2}\left({ }^{15} \varepsilon_{1}\right)$ can be determined as follows, when $\delta_{\mathrm{IN}}, \delta_{\mathrm{RS}}$, and $f$ are measured experimentally:

$$
\begin{gathered}
{ }^{15} \varepsilon_{1}=\left(\delta_{\mathrm{RS}}-\delta_{\mathrm{IN}}\right) / \mathrm{f} \\
f=\left(\mathrm{C}_{\mathrm{in}-\mathrm{NH} 4+}-\mathrm{C}_{\mathrm{out}-\mathrm{NH} 4+}\right) / \mathrm{C}_{\mathrm{in}-\mathrm{NH} 4+}
\end{gathered}
$$

where $\mathrm{C}_{\text {in-NH4+ }}$ and $\mathrm{C}_{\text {out-NH4+ }}$ are the $\mathrm{NH}_{4}{ }^{+}$concentrations of MBR influent and effluent, respectively.

\section{$\mathrm{N}$ isotope effects of $\mathrm{NO}_{2}^{-}$reduction and oxidation}

Nitrite $\left(\mathrm{NO}_{2}{ }^{-}\right)$is also continuously fed together with $\mathrm{NH}_{4}{ }^{+}$ into the $\mathrm{MBR}$ where $\mathrm{NO}_{2}{ }^{-}$reduction to $\mathrm{N}_{2}$ and $\mathrm{NO}_{2}{ }^{-}$ oxidation to $\mathrm{NO}_{3}{ }^{-}$concomitantly occur with fractionations (defined as ${ }^{15} \varepsilon_{3}$ and ${ }^{15} \varepsilon_{5}$, respectively), and unused residual $\mathrm{NO}_{2}{ }^{-}$exits the MBR without further fractionation (i.e., ${ }^{15} \varepsilon_{4}=0$ ) (Fig. 2b). The isotope compositions of product $\mathrm{N}_{2}$ $\left(\delta_{\text {product } 1}\right)$, product $\mathrm{NO}_{3}{ }^{-}\left(\delta_{\text {product } 2}\right)$, and residual $\mathrm{NO}_{2}{ }^{-}\left(\delta_{\mathrm{RS}}\right)$ at steady state can be given simply by subtracting $\varepsilon$ fractionations from the isotope composition of intermediate $\operatorname{pool}\left(\delta_{\mathrm{p}}\right)$ :

$$
\begin{aligned}
& \delta_{\text {product } 1}=\delta_{\mathrm{p}}-{ }^{15} \varepsilon_{3} \\
& \delta_{\mathrm{RS}}=\delta_{\mathrm{p}}-{ }^{15} \varepsilon_{4}=\delta_{\mathrm{p}}\left({ }^{15} \varepsilon_{4}=0\right) \\
& \delta_{\text {product } 2}=\delta_{\mathrm{p}}-{ }^{15} \varepsilon_{5}
\end{aligned}
$$

Now it is assumed that input flux is 1 and output flux is divided into $\alpha, \beta$, and $\gamma$ (Fig. 2b)

$1=\alpha+\beta+\gamma$

where $\alpha$ is the fraction of $\mathrm{NO}_{2}{ }^{-}$converted to $\mathrm{N}_{2}$. It is represented by $\mathrm{NH}_{4}{ }^{+}$consumption, because $\mathrm{NH}_{4}{ }^{+}$and $\mathrm{NO}_{2}{ }^{-}$ react at 1:1 ratio to form $\mathrm{N}_{2}$ (excluding $\mathrm{NO}_{2}{ }^{-}$oxidation to $\mathrm{NO}_{3}{ }^{-}$from the overall anammox reaction).

$\alpha=\left(\mathrm{C}_{\text {in }-\mathrm{NH} 4+}-\mathrm{C}_{\text {out }-\mathrm{NH} 4+}\right) / \mathrm{C}_{\text {in }-\mathrm{NO} 2-}$

$\beta$ is the fraction of residual $\mathrm{NO}_{2}^{-}$(unused) at steady state, which is experimentally determined.

$\beta=\mathrm{C}_{\text {out }-\mathrm{NO} 2-} / \mathrm{C}_{\mathrm{in}-\mathrm{NO} 2-}$

$\gamma$ is the fraction of $\mathrm{NO}_{2}^{-}$oxidized to $\mathrm{NO}_{3}{ }^{-}$. Although $\gamma$ could be determined from the $\mathrm{NO}_{3}{ }^{-}$concentration in MBR effluent at steady state, the influence of heterotrophic denitrification and dissimilatory nitrate reduction to ammonium (DNRA) by anammox bacteria cannot be excluded. Therefore, $\gamma$ was determined as follows:

$\gamma=1-\alpha-\beta$

Applying Eqs. (5), (6), and (7) yields the following steady-state isotope mass balance:

$$
\begin{gathered}
\delta_{\mathrm{IN}}=\alpha \delta_{\text {product } 1}+\beta \delta_{\mathrm{RS}}+\gamma \delta_{\text {product2 }} \\
\delta_{\mathrm{IN}}=\alpha\left(\delta_{\mathrm{p}}-{ }^{15} \varepsilon_{3}\right)+\beta \delta_{\mathrm{p}}+\gamma\left(\delta_{\mathrm{p}}-{ }^{15} \varepsilon_{5}\right) \\
=(\alpha+\beta+\gamma) \delta_{\mathrm{p}}-\alpha^{15} \varepsilon_{3}-\gamma^{15} \varepsilon_{5} \\
=\delta_{\mathrm{p}}-\alpha^{15} \varepsilon_{3}-\gamma^{15} \varepsilon_{5}=\delta_{\mathrm{RS}}-\alpha^{15} \varepsilon_{3}-\gamma^{15} \varepsilon_{5}
\end{gathered}
$$

Therefore, ${ }^{15} \varepsilon_{3}$ and ${ }^{15} \varepsilon_{5}$ can be calculated as follows, when $\delta_{\mathrm{IN}}, \delta_{\mathrm{RS}}$, and $\delta_{\text {product2 }}$ are measured experimentally:

$$
\begin{aligned}
& { }^{15} \varepsilon_{3}=\left(\delta_{\mathrm{RS}}-\delta_{\mathrm{IN}}-\gamma^{15} \varepsilon_{5}\right) / \alpha \\
& { }^{15} \varepsilon_{5}=\delta_{\mathrm{RS}}-\delta_{\text {product2 }}
\end{aligned}
$$


$\delta_{\text {product2 }}$ in the Eqs. (7) and (16) is not simply $\delta_{\text {out-NO3- }}$ because the influent media contained $0.84-1.21 \mathrm{mmol}-\mathrm{N} / \mathrm{L}$ of $\mathrm{NO}_{3}{ }^{-}$, which was originated from the university ground water (Table $\mathrm{S} 1$ ). Thus, the background isotope ratio of $\mathrm{NO}_{3}{ }^{-}$should be considered.

Isotope mass balance

$$
\begin{aligned}
\delta_{\text {out-NO3 }-} \times \mathrm{C}_{\text {out }-\mathrm{NO} 3-}= & \delta_{\text {in-NO3 }-} \times \mathrm{C}_{\text {in }-\mathrm{NO} 3-} \\
& +\delta_{\text {produced-NO3 }-} \times \mathrm{C}_{\text {produced }-\mathrm{NO} 3-}
\end{aligned}
$$

Mass balance

$\mathrm{C}_{\text {out-NO3- }}=\mathrm{C}_{\mathrm{in}-\mathrm{NO} 3-}+\mathrm{C}_{\text {produced-NO3- }}$

Applying Eqs. (17) and (18) yields the following equation for $\delta_{\text {produced-NO3-: }}$

$$
\begin{aligned}
& \delta_{\text {produced-NO3- }}=\delta_{\text {product2 }}= \\
& \quad\left(\delta_{\text {out-NO3 }-} \times \mathrm{C}_{\text {out-NO3- }}-\delta_{\text {in-NO3 }-} \times \mathrm{C}_{\text {in-NO3- }}\right) \\
& / \mathrm{C}_{\text {produced-NO3- }}-
\end{aligned}
$$

\section{0 isotope effect of nitrite oxidation}

For calculation of oxygen isotope effect for nitrite oxidation $\left(\mathrm{NO}_{2}{ }^{-} \rightarrow \mathrm{NO}_{3}{ }^{-}\right)$, the produced $\mathrm{NO}_{3}{ }^{-}$contains three oxygen atoms: two oxygen atoms come from $\mathrm{NO}_{2}{ }^{-}$ and one oxygen atom comes from $\mathrm{H}_{2} \mathrm{O}$. The incorporation of an oxygen atom from water should be considered $\left({ }^{18} \varepsilon_{6}\right.$ in Fig. 2b). Thus, for oxygen isotopes, Eq. (7) is rewritten as

$$
\begin{aligned}
& \delta_{\text {product } 2}=2 / 3\left(\delta_{\mathrm{RS}}-{ }^{18} \varepsilon_{5}\right)+1 / 3\left(\delta_{\mathrm{H} 2 \mathrm{O}}-{ }^{18} \varepsilon_{6}\right) \\
& \delta_{\text {product } 2}=2 / 3 \delta_{\mathrm{RS}}+1 / 3 \delta_{\mathrm{H} 2 \mathrm{O}}-\left(2 / 3^{18} \varepsilon_{5}+1 / 3^{18} \varepsilon_{6}\right)
\end{aligned}
$$

${ }^{18} \varepsilon_{6}$ is the isotope effect for water incorporation. Since there are two unknown values $\left({ }^{18} \varepsilon_{5}\right.$ and $\left.{ }^{18} \varepsilon_{6}\right)$ in the Eq. (21), ${ }^{18} \varepsilon_{5}$ and ${ }^{18} \varepsilon_{6}$ cannot be calculated independently. Thus, the term $\left(2 / 3{ }^{18} \varepsilon_{5}+1 / 3{ }^{18} \varepsilon_{6}\right)$ in Eq. (21) is denoted as a combined oxygen isotope effect

${ }^{18} \mathrm{E}_{\mathrm{NO} 2 \rightarrow \mathrm{NO} 3-}$.

${ }^{18} \mathrm{E}_{\mathrm{NO} 2 \rightarrow \mathrm{NO} 3-}=$

$$
\left(2 / 3^{18} \varepsilon_{5}+1 / 3^{18} \varepsilon_{6}\right)=2 / 3 \delta_{\mathrm{RS}}+1 / 3 \delta_{\mathrm{H} 2 \mathrm{O}}-\delta_{\text {product} 2}
$$

This combined oxygen isotope effect can be calculated from the obtained data set in this study.

\section{Results}

\section{Reactor performance}

After the MBRs have reached a steady state, three or four sub-samples of MBR influent and effluent (permeate) were taken and analyzed for the concentrations and $\mathrm{N}$ and $\mathrm{O}$ isotope ratios of $\mathrm{NH}_{4}{ }^{+}, \mathrm{NO}_{2}{ }^{-}$, and $\mathrm{NO}_{3}{ }^{-}$, respectively. The steady-state concentrations of $\mathrm{NH}_{4}{ }^{+}, \mathrm{NO}_{2}{ }^{-}$, and $\mathrm{NO}_{3}{ }^{-}$in the MBR effluents were very stable during the entire experiments (Tables $\mathrm{S} 1$ and 1 ). $\mathrm{NO}_{2}{ }^{-}$was almost completely consumed, whereas $1.3-3.1 \mathrm{mM} \mathrm{NH}_{4}^{+}$remained in all the MBR effluents and a small amount of $\mathrm{NO}_{3}{ }^{-}$was produced. The average stoichiometric ratios of consumed $\mathrm{NO}_{2}{ }^{-}$and consumed $\mathrm{NH}_{4}{ }^{+}\left(\Delta \mathrm{NO}_{2}{ }^{-} / \Delta \mathrm{NH}_{4}{ }^{+}\right.$, ranging from $1.11 \pm 0.5$ to $1.28 \pm 0.5)$ and produced $\mathrm{NO}_{3}{ }^{-}$and consumed $\mathrm{NH}_{4}{ }^{+}\left(\Delta \mathrm{NO}_{3}{ }^{-} / \Delta \mathrm{NH}_{4}{ }^{+}\right.$, ranging from $0.10 \pm 0.01$ to $0.2 \pm$ 0.03 ) (Table 1) agreed with the previously observed stoichiometry of anammox process (i.e. 1.15 and 0.16 for $\Delta \mathrm{NO}_{2}{ }^{-} / \Delta \mathrm{NH}_{4}{ }^{+}$and $\Delta \mathrm{NO}_{3}{ }^{-} / \Delta \mathrm{NH}_{4}{ }^{+}$, respectively) [49], suggesting that the anammox process being responsible for transformation of nitrogen compounds occurring in all three MBRs.

Although influent $\mathrm{NH}_{4}{ }^{+}$and $\mathrm{NO}_{2}{ }^{-}$concentrations were different ( $10 \mathrm{mM}$ for "Ca. S. japonica", $10 \mathrm{mM}$ for "Ca. J. caeni" and $16 \mathrm{mM}$ for "Ca. B. sinica"), anammox activity in each MBR culture was consistent as demonstrated by similar volumetric $\mathrm{NH}_{4}{ }^{+}$consumption, $\mathrm{NO}_{2}{ }^{-}$consumption, and $\mathrm{NO}_{3}{ }^{-}$production rates (Table 1). Furthermore, there were no significant difference in specific $\mathrm{NH}_{4}{ }^{+}$consumption rates (ranging from $1.14 \pm 0.06$ to $1.27 \pm 0.06 \mathrm{mg}-\mathrm{N}$ mg-protein ${ }^{-1} \mathrm{~h}^{-1}$ ), $\mathrm{NO}_{2}{ }^{-}$consumption rates (ranging from $1.41 \pm 0.05$ to $1.48 \pm 0.04 \mathrm{mg}-\mathrm{N} \mathrm{mg}$-protein $\left.{ }^{-1} \mathrm{~h}^{-1}\right)$, and $\mathrm{NO}_{3}{ }^{-}$production rates (ranging from $0.11 \pm 0.01$ to $0.24 \pm$ $0.03 \mathrm{mg}-\mathrm{N}$ mg-protein ${ }^{-1} \mathrm{~h}^{-1}$ ) among three MBR cultures.

The ratio of anammox bacteria to the cell culture (degree of enrichment cultures) was determined by fluorescent in situ hybridization (FISH); $94.4 \pm 6.5 \%$ for " $\mathrm{Ca}$. S. japonica", $86.1 \pm 4.9 \%$ for "Ca. J. caeni", and $96.9 \pm 2.6 \%$ for "Ca. B. sinica", respectively.

\section{Nitrogen isotope effects $\left({ }^{15} \varepsilon\right)$}

The culture media with an equimolar amount of $\mathrm{NH}_{4}^{+}$ $\left(\delta^{15} \mathrm{~N}_{\mathrm{IN}}=-7.0 \pm 0.3 \%\right.$ o to $\left.-2.4 \pm 0.2 \% 0\right)$ and $\mathrm{NO}_{2}{ }^{-}\left(\delta^{15} \mathrm{~N}_{\mathrm{IN}}\right.$ $=-3.7 \pm 0.1 \%$ o to $-2.6 \pm 0.7 \% \circ$ and $\delta^{18} \mathrm{O}_{\mathrm{IN}}=6.0 \pm 0.5 \%$ to $8.1 \pm 0.7 \%$ ) were continuously fed to the individual MBR cultures (Table 1). $\mathrm{N}$ isotope effects of $\mathrm{NH}_{4}{ }^{+}$oxidation to $\mathrm{N}_{2}\left({ }^{15} \varepsilon_{\mathrm{NH} 4 \rightarrow \mathrm{N} 2}\right), \mathrm{NO}_{2}{ }^{-}$reduction to $\mathrm{N}_{2}\left({ }^{15} \varepsilon_{\mathrm{NO} 2 \rightarrow \mathrm{N} 2}\right)$, and $\mathrm{NO}_{2}{ }^{-}$oxidation to $\mathrm{NO}_{3}{ }^{-}\left({ }^{15} \varepsilon_{\mathrm{NO} 2 \rightarrow \mathrm{NO} 3}\right)$ were calculated for all three species using the equations described in "Materials 
Table 1 Summary of MBR performance and $\mathrm{N}$ and $\mathrm{O}$ isotope analyses

\begin{tabular}{|c|c|c|c|c|c|c|}
\hline \multirow{2}{*}{$\begin{array}{l}\text { Species } \\
\text { Input and Output }\end{array}$} & \multicolumn{2}{|c|}{ "Ca. Scalindua japonica" } & \multicolumn{2}{|c|}{ "Ca. Jettenia caeni" } & \multicolumn{2}{|c|}{ "Ca. Brocadia sinica" } \\
\hline & In & Out & In & Out & In & Out \\
\hline \multicolumn{7}{|l|}{ Concentration (mmol-N/L) } \\
\hline $\mathrm{NH}_{4}^{+}$ & $10.5 \pm 0.5$ & $1.5 \pm 0.2$ & $9.3 \pm 0.6$ & $1.6 \pm 0.2$ & $16.1 \pm 0.6$ & $2.6 \pm 0.4$ \\
\hline $\mathrm{NO}_{2}^{-}$ & $10.0 \pm 0.4$ & $0.01 \pm 0.00$ & $9.9 \pm 0.3$ & $0.03 \pm 0.01$ & $16.5 \pm 0.6$ & $0.21 \pm 0.16$ \\
\hline $\mathrm{NO}_{3}^{-}$ & $0.85 \pm 0.01$ & $1.72 \pm 0.08$ & $0.96 \pm 0.02$ & $1.74 \pm 0.09$ & $0.93 \pm 0.01$ & $3.55 \pm 0.33$ \\
\hline $\mathrm{NO}_{3}{ }^{-}$produced & $0.87 \pm 0.08$ & & $0.78 \pm 0.08$ & & $2.63 \pm 0.34$ & \\
\hline \multicolumn{7}{|l|}{ Fraction reacted } \\
\hline$f$ & $0.86 \pm 0.01$ & & $0.83 \pm 0.02$ & & $0.84 \pm 0.02$ & \\
\hline$\alpha$ & $0.90 \pm 0.04$ & & $0.78 \pm 0.03$ & & $0.82 \pm 0.02$ & \\
\hline$\beta$ & $0.00088 \pm 0.00032$ & & $0.0033 \pm 0.0011$ & & $0.012 \pm 0.009$ & \\
\hline$\gamma$ & $0.097 \pm 0.04$ & & $0.21 \pm 0.03$ & & $0.17 \pm 0.01$ & \\
\hline \multicolumn{7}{|l|}{$\delta^{15} N(\% \circ)$} \\
\hline $\mathrm{NH}_{4}^{+}$ & $-2.8 \pm 0.1$ & $25.4 \pm 0.3$ & $-7.0 \pm 0.3$ & $19.5 \pm 2.6$ & $-2.4 \pm 0.2$ & $23.4 \pm 0.7$ \\
\hline $\mathrm{NO}_{2}^{-}$ & $-3.1 \pm 0.1$ & $12.0 \pm 1.9$ & $-2.6 \pm 0.7$ & $10.6 \pm 0.7$ & $-3.7 \pm 0.1$ & $-4.3 \pm 4.6$ \\
\hline $\mathrm{NO}_{3}^{-}$ & $12.4 \pm 0.3$ & $27.3 \pm 0.2$ & $13.3 \pm 0.2$ & $32.2 \pm 0.8$ & $15.3 \pm 0.1$ & $24.1 \pm 0.9$ \\
\hline $\mathrm{NO}_{3}^{-}$produced & $42.0 \pm 1.5$ & & $55.9 \pm 4.7$ & & $27.2 \pm 0.95$ & \\
\hline \multicolumn{7}{|l|}{$\delta^{18} O(\% \circ)$} \\
\hline $\mathrm{NO}_{2}^{-}$ & $6.0 \pm 0.5$ & $6.4 \pm 0.2$ & $8.1 \pm 0.7$ & $5.2 \pm 0.3$ & $6.3 \pm 0.4$ & $4.9 \pm 1.4$ \\
\hline $\mathrm{NO}_{3}^{-}$ & $1.1 \pm 0.1$ & $6.9 \pm 0.1$ & $-1.7 \pm 0.4$ & $-0.2 \pm 0.6$ & $0.8 \pm 0.2$ & $1.0 \pm 0.3$ \\
\hline $\mathrm{NO}_{3}{ }^{-}$produced & $12.7 \pm 0.8$ & & $1.7 \pm 0.8$ & & $1.0 \pm 0.4$ & \\
\hline $\mathrm{NH}_{4}^{+}$removal rate $\left(\mathrm{kg} \mathrm{m}^{-3} \mathrm{~d}^{-1}\right)$ & $0.127 \pm 0.006$ & & $0.119 \pm 0.006$ & & $0.188 \pm 0.003$ & \\
\hline $\mathrm{NO}_{2}^{-}$removal rate $\left(\mathrm{kg} \mathrm{m}^{-3} \mathrm{~d}^{-1}\right)$ & $0.140 \pm 0.005$ & & $0.152 \pm 0.004$ & & $0.228 \pm 0.006$ & \\
\hline $\mathrm{NO}_{3}^{-}$production rate $\left(\mathrm{kg} \mathrm{m}^{-3} \mathrm{~d}^{-1}\right)$ & $0.012 \pm 0.001$ & & $0.012 \pm 0.001$ & & $0.037 \pm 0.005$ & \\
\hline $\begin{array}{l}\text { Specific } \mathrm{NH}_{4}^{+} \text {consumption rate } \\
(\mathrm{mg}-\mathrm{N} \text { mg-protein }\end{array}$ & $1.27 \pm 0.06$ & & $1.14 \pm 0.06$ & & $1.22 \pm 0.02$ & \\
\hline $\begin{array}{l}\text { Specific } \mathrm{NO}_{2}^{-} \text {consumption rate } \\
\left(\mathrm{mg}-\mathrm{N} \text { mg-protein }{ }^{-1} \mathrm{~h}^{-1}\right)\end{array}$ & $1.41 \pm 0.05$ & & $1.45 \pm 0.04$ & & $1.48 \pm 0.04$ & \\
\hline  & $0.12 \pm 0.01$ & & $0.11 \pm 0.01$ & & $0.24 \pm 0.03$ & \\
\hline$\Delta \mathrm{NO}_{2}{ }^{-} / \Delta \mathrm{NH}_{4}^{+}$ & $1.11 \pm 0.05$ & & $1.28 \pm 0.05$ & & $1.21 \pm 0.02$ & \\
\hline$\Delta \mathrm{NO}_{3}{ }^{-} / \Delta \mathrm{NH}_{4}{ }^{+}$ & $0.10 \pm 0.01$ & & $0.10 \pm 0.01$ & & $0.20 \pm 0.03$ & \\
\hline
\end{tabular}

and methods" (Fig. 3 and Table S1). In the case of $\mathrm{NH}_{4}{ }^{+}$ oxidation to $\mathrm{N}_{2}$, the values of ${ }^{15} \varepsilon_{\mathrm{NH} 4 \rightarrow \mathrm{N} 2}$ were consistent among three species $(30.9 \pm 0.2 \% 0-32.7 \pm 0.7 \%$ o. In contrast, there were significant differences in the ${ }^{15} \varepsilon_{\mathrm{NO} 2 \rightarrow \mathrm{N} 2}$ values $\left(\mathrm{NO}_{2}{ }^{-}\right.$reduction to $\left.\mathrm{N}_{2}\right)$. "Ca. J. caeni" showed the largest value $(29.5 \pm 3.9 \%$ ), whereas " $\mathrm{Ca}$. B. sinica" yielded the smallest value $(5.9 \pm 4.5 \%)$. The value of " $\mathrm{Ca}$. $\mathrm{S}$. japonica" was ${ }^{15} \varepsilon_{\mathrm{NO} 2 \rightarrow \mathrm{N} 2}=19.9 \pm 1.7 \%$ o, which was close to the previously reported value of " $\mathrm{Ca}$. K. stuttgartiensis" $\left(16.0 \pm 4.5 \%\right.$ ) [32]. In the case of $\mathrm{NO}_{2}{ }^{-}$oxidation to $\mathrm{NO}_{3}{ }^{-}$, all three species showed strong inverse kinetic isotope effects $\left({ }^{15} \varepsilon_{\mathrm{NO} 2 \rightarrow \mathrm{NO} 3}<0\right)$; $-30.1 \pm 3.0 \%$ for " $\mathrm{Ca}$. S. japonica", $-45.3 \pm 4.2 \%$ o for "Ca. J. caeni", and $-31.5 \pm 4.0 \%$ for "Ca. B. sinica", respectively (Fig. 3 and Table S1), which consists with the previously reported value of " $\mathrm{Ca} . \mathrm{K}$. stuttgartiensis" $(-31.1 \pm 3.9 \%$ ) [32].

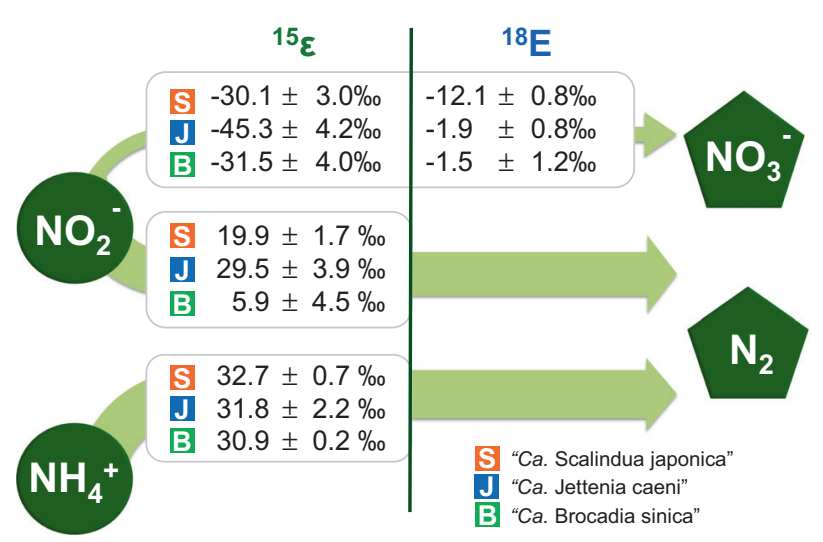

Fig. 3 Summary of $\mathrm{N}$ and $\mathrm{O}$ isotope effects induced by different anammox species 


\section{Oxygen isotope effect $\left({ }^{18} \varepsilon\right)$}

$\delta^{18} \mathrm{O}_{\mathrm{H} 2 \mathrm{O}}$ of ground water which was used for medium preparation was determined to be $-11.12 \% \circ \pm 0.2 \% \circ(n=3)$ and remained stable during an entire experimental period. Both $\delta^{18} \mathrm{O}_{\mathrm{NO} 2-}$ and $\delta^{18} \mathrm{O}_{\mathrm{NO} 3-}$ in MBR influents were consistent among three anammox cultures, respectively (Table 1). Under steady-state conditions, similar values of $\delta^{18} \mathrm{O}_{\mathrm{NO} 2}$ - were determined in all three MBR effluents; $6.4 \pm 0.2 \%$ for "Ca. S. japonica", $5.2 \pm 0.3 \%$ o for " $\mathrm{Ca}$. J. caeni", and $4.9 \pm 1.4 \%$ or " $C a$. B. sinica", respectively (Table 1). In contrast, the "Ca. S. japonica" MBR yielded a

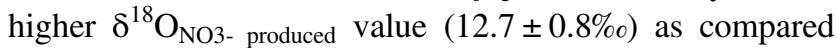
with those of "Ca. J. caeni" $(1.7 \pm 0.8 \%$ o) and "Ca. B. sinica" $\left(1.0 \pm 0.4 \%\right.$ ) . Based on these $\delta^{18} \mathrm{O}$ data, the combined $\mathrm{O}$ isotope effect during $\mathrm{NO}_{2}{ }^{-}$oxidation to $\mathrm{NO}_{3}{ }^{-}$ was calculated for all three species using the Eq. (22) $\left({ }^{18} \mathrm{E}_{\mathrm{NO} 2 \rightarrow \mathrm{NO} 3}=\left(\begin{array}{lll}2 / 3 & { }^{18} \varepsilon_{5}+1 / 3 & { }^{18} \varepsilon_{6}\end{array}\right)=2 / 3 \delta_{\mathrm{RS}}+1 / 3 \delta_{\mathrm{H} 2 \mathrm{O}}\right.$ $-\delta_{\text {product2 }}$ ) (Table S1 and Fig. 3). All three species showed inverse kinetic isotope effects; $-12.1 \pm 0.8 \%$ o for " $\mathrm{Ca}$. $\mathrm{S}$. japonica", $-1.9 \pm 0.8 \%$ for "Ca. J. caeni", and $-1.5 \pm$ $1.2 \%$ o for "Ca. B. sinica", respectively.

\section{Discussion}

\section{Continuous culture method}

In this study, the $\mathrm{N}$ and $\mathrm{O}$ isotope effects induced by anammox bacteria were measured using continuous MBR anammox-enrichment cultures. There are some advantages of use of the continuous culture system over batch system. A steady-state fractionation model is basically simpler than a batch model such as the Rayleigh model, in which the isotope effect $(\varepsilon)$ values can be directly determined from the isotopic compositions of reactants in the influent and products in the effluent at steady state (Fig. 2). Nearly identical results of the $\mathrm{N}$ and $\mathrm{O}$ isotope effects were obtained from the different sampling campaigns for "Ca. B. sinica" (Table S2), which indicates the high reproducibility of continuous steady-state culturing systems for isotope effect analyses (Table S3). The precision of ${ }^{15} \varepsilon$ and ${ }^{18} \varepsilon$ as measured in the steady-state continuous systems compares favorably with that of batch culture experiments [7].

In addition, growth conditions (i.e., $\mathrm{pH}$, concentrations of reactants and products, and so on) vary over time, which may also significantly affect the isotope fractionations. However, oxygen isotope exchange between $\mathrm{NO}_{2}{ }^{-}$and $\mathrm{H}_{2} \mathrm{O}$ cannot be evaluated in the continuous culture experiment alone, and thus batch culture experiments must be conducted in parallel.

\section{Species-level differences}

Among five tentatively proposed candidatus genera of anammox bacteria, one putative marine strain (' $\mathrm{Ca}$. Scalindua japonica') and two freshwater strains (' $\mathrm{Ca}$. Brocadia sinica' and 'Ca. Jettenia caeni') were examined for $\mathrm{N}$ and $\mathrm{O}$ isotope effects of anammox metabolism in this study. The results revealed species-dependent isotope effects of $\mathrm{NO}_{2}{ }^{-}$reduction to $\mathrm{N}_{2}$. During anammox metabolism $\left(\mathrm{NO}_{2}{ }^{-}+\mathrm{NH}_{4}{ }^{+} \rightarrow \mathrm{N}_{2}\right)$, the following three enzymatic reactions occur; (i) $\mathrm{NO}_{2}{ }^{-}$ reduction to nitric oxide (NO) or hydroxylamine $\left(\mathrm{NH}_{2} \mathrm{OH}\right)$ [51], (ii) hydrazine $\left(\mathrm{N}_{2} \mathrm{H}_{4}\right)$ formation from $\mathrm{NO}$ or $\mathrm{NH}_{2} \mathrm{OH}$ and $\mathrm{NH}_{4}^{+}$, and (iii) $\mathrm{N}_{2} \mathrm{H}_{4}$ oxidation to $\mathrm{N}_{2}$ [25]. Hydrazine synthesis is considered to be the rate-limiting step in this reaction sequence due to three-electron reduction reaction [25].

For the conversion of $\mathrm{NH}_{4}^{+}$to $\mathrm{N}_{2}$, the $\mathrm{N}$ isotope effects $\left({ }^{15} \varepsilon_{\mathrm{NH} 4 \rightarrow \mathrm{N} 2}\right)$ of all three species are consistent (30.9-32.7\%o), which also do not significantly differ from the range of ${ }^{15} \varepsilon_{\mathrm{NH} 4 \rightarrow \mathrm{N} 2}$ reported previously for " $\mathrm{Ca}$. $\mathrm{K}$. stuttgartiensis" (23.5-29.1\%o) [32]. This is probably because this reaction is mediated through the same enzymes, such as hydrazine synthase (hzs) and hydrazine dehydrogenase (hdh) in all anammox bacteria species (Fig. 4).

On the other hand, for the conversion of $\mathrm{NO}_{2}{ }^{-}$to $\mathrm{N}_{2}$, significant variations of the $\mathrm{N}$ isotope effects $\left({ }^{15} \varepsilon_{\mathrm{NO} 2 \rightarrow \mathrm{N} 2}\right)$ were found among the three species: ${ }^{15} \varepsilon_{\mathrm{NO} 2 \rightarrow \mathrm{N} 2}=19.9 \pm$ $1.7 \%$ for "Ca. S. japonica", ${ }^{15} \varepsilon_{\mathrm{NO} 2 \rightarrow \mathrm{N} 2}=29.5 \pm 3.9 \%$ for "Ca. J. caeni", and ${ }^{15} \varepsilon_{\mathrm{NO} 2 \rightarrow \mathrm{N} 2}=5.9 \pm 4.5 \%$ or for "Ca. B. sinica", respectively (Fig. 3 and Table S1.). The previously reported ${ }^{15} \varepsilon_{\mathrm{NO} 2 \rightarrow \mathrm{N} 2}$ values of " $\mathrm{Ca}$. K. stuttgartiensis" ranged between $11.9 \%$ ond $18.9 \%$ (average $=16.0 \pm 4.5 \%$ o) [32].

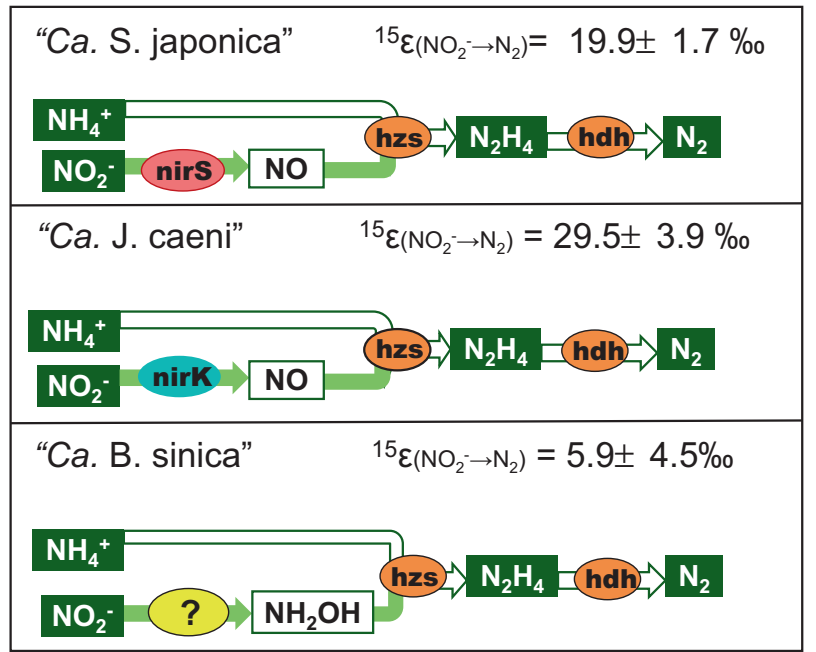

Fig. 4 Proposed species-level difference in $\mathrm{N}$ isotope effects of nitrite $\left({ }^{15} \varepsilon_{\mathrm{NO} 2 \rightarrow \mathrm{N} 2}\right)$ induced by different anammox bacteria species 
Different degree of $\mathrm{N}$ isotopic fractionation could be imparted by different nitrite reductase (Fig. 4). It has been reported that "Ca. S. japonica" and "Ca. K. stuttgartiensis" possess a cytochrome $c d_{l}$ (iron, Fe)-type NO-forming nitrite reductase (Fe-NIR) [52, 53], whereas "Ca. J. caeni" has a copper $(\mathrm{Cu})$-containing NO-forming nitrite reductase (Cu-NIR) [40]. "Ca. B. sinica”, however, does not possess canonical nitrite reductase genes (neither Fe-NIR nor $\mathrm{Cu}$ NIR) and reduces $\mathrm{NO}_{2}{ }^{-}$to $\mathrm{NH}_{2} \mathrm{OH}$, instead of $\mathrm{NO}$ [51]. Interestingly, both " $\mathrm{Ca}$. S. japonica" and " $\mathrm{Ca}$. K. stuttgartiensis" yielded similar ${ }^{15} \varepsilon_{\mathrm{NO} 2 \rightarrow \mathrm{N} 2}$ values $\left({ }^{15} \varepsilon_{\mathrm{NO} 2 \rightarrow \mathrm{N} 2}=19.9\right.$ $\pm 1.7 \%$ and $16.0 \pm 4.5 \%$ ), while "Ca. J. caeni" yielded higher values $\left({ }^{15} \varepsilon_{\mathrm{NO} 2 \rightarrow \mathrm{N} 2}=29.5 \pm 3.9 \%\right.$ ). Furthermore, "Ca. B. sinica" yielded distinctively lower ${ }^{15} \varepsilon_{\mathrm{NO} 2 \rightarrow \mathrm{N} 2}$ values $(5.9 \pm 4.5 \%$ ) (Fig. 4). The different $\mathrm{N}$ and $\mathrm{O}$ isotope effects between Fe-NIR and $\mathrm{Cu}-\mathrm{NIR}$ were also demonstrated for nitrite reduction by denitrifying bacteria [11]. This difference was explained by the difference in $\mathrm{NO}_{2}{ }^{-}$and enzymebinding mechanism: the $\mathrm{Cu}-\mathrm{NIR}$ binds to both $\mathrm{O}$ atoms of $\mathrm{NO}_{2}{ }^{-}$whereas the Fe-NIR binds to the $\mathrm{N}$ atom, resulting in a smaller $\mathrm{N}$ isotope effect for Fe-NIR [11].

However, the recent literatures have reported that FeNirS was not hardly expressed at the transcriptional level in both "Ca. K. stuttgartiensis" [54] and Scalindua-related single amplified genomes from ODZs $[55,56]$. In addition, $\mathrm{Cu}-\mathrm{NirK}$ expression was not identified in "Ca. J. caeni" [40]. It has been postulated recently that the reduction of $\mathrm{NO}_{2}{ }^{-}$to $\mathrm{NO}$ could be catalyzed by a HAO-like octahaem oxidoreductase in the case of "Ca. K. stuttgartiensis" [54]. The highly similar protein was also identified in the ODZ SAGs [56]. "Ca. B. sinica" that has neither NirS nor NirK also possesses the identical HAO-like octahaem oxidoreductase [51]. However, nitrite reductase that actually works in individual anammox species is not identified yet. To confirm this enzyme-level differences in ${ }^{15} \varepsilon_{\mathrm{NO} 2 \rightarrow \mathrm{N} 2}$, true nitrite reductase must be identified.

Three anammox bacterial species were cultured at different $\mathrm{pH}$ and temperature in this study; $\mathrm{pH} 7.9-8.0$ and 25 ${ }^{\circ} \mathrm{C}$ for "Ca. S. japonica", $\mathrm{pH} 8.6-8.9$ and $30^{\circ} \mathrm{C}$ for " Ca. J. caeni", and $\mathrm{pH} 7.3-7.4$ and $37^{\circ} \mathrm{C}$ for " $\mathrm{Ca}$. B. sinica", respectively. However, this probably does not cause variations in ${ }^{15} \varepsilon_{\mathrm{NO} 2 \rightarrow \mathrm{N} 2}$. To our best knowledge, there were no studies that show a dependence of the organism-level $\mathrm{N}$ isotope effect on either $\mathrm{pH}$ or temperature so far, although temperature and $\mathrm{pH}$ influence the $\mathrm{O}$ isotope effect of $\mathrm{NO}_{2}{ }^{-}$ due to isotopic exchange with $\mathrm{H}_{2} \mathrm{O}[8,57]$. Taken together, a difference in nitrite reductase would most likely cause the differences in $\mathrm{NO}_{2}{ }^{-}$reduction isotope effects $\left({ }^{15} \varepsilon_{\mathrm{NO} 2 \rightarrow \mathrm{N} 2}\right)$ in this study.

For the oxidation of $\mathrm{NO}_{2}{ }^{-}$to $\mathrm{NO}_{3}{ }^{-}$, all three anammox species exhibited pronounced inverse $\mathrm{N}$ isotope effects $(-45.3 \pm 4.2 \%$ o to $-30.1 \pm 3.0 \%$, which agreed with the previously reported value for " $\mathrm{Ca}$. $\mathrm{K}$. stuttgartiensis"
$(-31.1 \% \circ \pm 3.9 \%$ [ [32], but exceeded the values for nitriteoxidizing bacteria (NOB) $(-9.1 \%$ o to $-20.6 \%$ ) [10]. Anammox bacteria can reverse this enzymatic reaction, namely they can reduce $\mathrm{NO}_{3}{ }^{-}$back to $\mathrm{NO}_{2}{ }^{-}[58,59]$. It is thus hypothesized that this reversible reaction would promote isotope exchange between $\mathrm{NO}_{2}{ }^{-}$and $\mathrm{NO}_{3}{ }^{-}$and lead to more pronounced isotope effects as observed in sulfur metabolism [60]. Intriguingly, it has been also speculated that environmental stresses cause a significant $\mathrm{N}$ isotope exchange between $\mathrm{NO}_{2}{ }^{-}$and $\mathrm{NO}_{3}{ }^{-}(-60.5 \pm 1.0 \%$ ) in a "Ca. K. stuttgartiensis" batch culture [32]. However, since this phenomenon was not ubiquitously observed, it still remained unclear whether this was caused by cell lysis during cultivation and/or sample preparation. In the present study, all samples for isotope effect measurements were collected from steady-state continuous anammoxenrichment cultures grown under physiological anoxic conditions. Thus, environmental stresses could be minimized, and active biomass dominated in all cultures ( $>98 \%$ were active cells as determined Live/Dead staining, data not shown). Since isotope exchange between $\mathrm{NO}_{2}{ }^{-}$and $\mathrm{NO}_{3}{ }^{-}$ is indeed an interesting and important phenomenon for interpretation of the $\mathrm{N}$ and $\mathrm{O}$ isotope effects, it must be addressed in the future.

It should be also noted that $\mathrm{N}$ and $\mathrm{O}$ isotope effects are influenced even by subcellular localization and amino acid sequences of enzymes (Fig. S2). For example, membranebound cytoplasmic and periplasmic Nxr of Nitrobacter and Nitrospira yielded significantly different ${ }^{15} \varepsilon_{\mathrm{NO} 2 \rightarrow \mathrm{NO} 3-}$ and ${ }^{18} \varepsilon_{\mathrm{NO} 2 \rightarrow \mathrm{NO} 3-}[10]$. However, since the actual subcellular localization and amino acid sequences of enzymes in anammox bacteria are not fully understood currently, their influences need to be further investigated.

\section{$\mathrm{O}$ isotope effects of $\mathrm{NO}_{2}^{-}$and $\mathrm{NO}_{3}{ }^{-}$}

We could report only the combined $\mathrm{O}$ isotope effects for $\mathrm{NO}_{2}^{-}$oxidation to $\mathrm{NO}_{3}^{-} \quad\left({ }^{18} \mathrm{E}_{\mathrm{NO} 2 \rightarrow \mathrm{NO} 3-}=2 / 3\right.$ ${ }^{18} \varepsilon_{\mathrm{NO} 2 \rightarrow \mathrm{NO} 3-}+1 / 3{ }^{18} \varepsilon_{\mathrm{H} 2 \mathrm{O}}$, Eq. (22)) by anammox bacteria in this study. Since both $\mathrm{NO}_{2}{ }^{-}$reduction to $\mathrm{N}_{2}$ and oxidation to $\mathrm{NO}_{3}{ }^{-}$are simultaneously occurring in anammox process (Fig. S3B), the $\delta^{18} \mathrm{O}$ values of $\mathrm{NO}_{2}^{-}$represents a superimposed signal of the two processes. In addition, the $\delta^{18} \mathrm{O}_{\mathrm{NO} 2}$ value is affected by abiotic $\mathrm{O}$ isotope exchange between $\mathrm{NO}_{2}{ }^{-}$and $\mathrm{H}_{2} \mathrm{O}\left({ }^{18} \varepsilon_{\text {eq }}\right.$ in Fig. S3). A water-derived $\mathrm{O}$ atom is also incorporated into $\mathrm{NO}_{3}{ }^{-}$during $\mathrm{NO}_{2}{ }^{-}$oxidation to $\mathrm{NO}_{3}{ }^{-}$[61]. Therefore, the $\delta^{18} \mathrm{O}_{\mathrm{NO}}$ value of the MBR effluent is directly related to the culture medium (water) $\delta^{18} \mathrm{O}_{\mathrm{H} 2 \mathrm{O}}$ through both $\mathrm{O}$ isotope equilibration of $\mathrm{NO}_{2}{ }^{-}\left({ }^{18} \varepsilon_{\mathrm{eq}}\right)$ and incorporation of a water-derived $\mathrm{O}$ atom $\left({ }^{18} \varepsilon_{\mathrm{H} 2 \mathrm{O}}\right)$ [26]. Thus, $\mathrm{O}$ isotope effect for $\mathrm{NO}_{2}{ }^{-}$oxidation to $\mathrm{NO}_{3}{ }^{-}\left({ }^{18} \varepsilon_{\mathrm{NO} 2-\rightarrow \mathrm{NO}} 3_{-}\right)$and $\mathrm{O}$ isotope effect for water incorporation $\left({ }^{18} \varepsilon_{\mathrm{H} 2 \mathrm{O}}\right)$ cannot be determined separately in 
the continuous culture experiment alone in this study. These parameters could be species dependent and thus should be separately determined for individual anammox bacteria species for better understanding of $\mathrm{N}$ and $\mathrm{O}$ isotope systematics and nitrogen cycling in natural environments.

The combined $\mathrm{O}$ isotope effects for $\mathrm{NO}_{2}{ }^{-}$oxidation $\left({ }^{18} \mathrm{E}_{\mathrm{NO} 2 \rightarrow \mathrm{NO} 3-}\right)$ showed inverse kinetic isotope effects; ${ }^{18} \mathrm{E}_{\mathrm{NO} 2} \rightarrow \mathrm{NO} 3:-12.1 \pm 0.8 \%$ o for "Ca. S. japonica", $-1.9 \pm$ $0.8 \%$ o for "Ca. J. caeni" and $-1.5 \pm 1.2 \%$ o for " $\mathrm{Ca}$. B. sinica", respectively (Fig. 3 and Table S1). According to the Eq. (22) for the combined $\mathrm{O}$ isotope effect $\left({ }^{18} \mathrm{E}_{\mathrm{NO} 2-\mathrm{NO} 3-}\right.$ $\left.=2 / 3{ }^{18} \varepsilon_{\mathrm{NO} 2 \rightarrow \mathrm{NO} 3-}+1 / 3{ }^{18} \varepsilon_{\mathrm{H} 2 \mathrm{O}}\right),{ }^{18} \varepsilon_{\mathrm{NO} 2 \rightarrow \mathrm{NO} 3}$ by anammox bacteria can be estimated when $\mathrm{O}$ isotope effect for water incorporation $\left({ }^{18} \varepsilon_{\mathrm{H} 2 \mathrm{O}}\right)$ was assumed to be $14 \%$ as assumed for NOB previously $[18,26]:-25.2 \%$ o for " $C a$. $S$. japonica", $-9.9 \%$ for "Ca. J. caeni", and $-9.3 \%$ o for " $\mathrm{Ca}$. $B$. sinica", respectively. Aerobic nitrite oxidizing bacteria (NOB) also yielded inverse kinetic isotope effects of $\mathrm{NO}_{2}{ }^{-}$ oxidation $\left({ }^{18} \varepsilon_{\mathrm{NO} 2 \rightarrow \mathrm{NO} 3}\right)$ ranging from $-1.3 \pm 0.4 \%$ to $-8.2 \pm 2.5 \%$ o [9]. It should be noted again that we report a combined O isotope effect (Eq. (22)) whereas Buchwald and Casciotti [9] report the kinetic isotope effect on $\mathrm{NO}_{2}{ }^{-}$ alone (equivalent to ${ }^{18} \varepsilon_{5}$ in Eq. (20)).

The rate of abiotic $\mathrm{O}$ isotope exchange between $\mathrm{NO}_{2}{ }^{-}$ and $\mathrm{H}_{2} \mathrm{O}$ is rapid relative to the biological $\mathrm{NO}_{2}{ }^{-}$turnover rate and dependent on temperature and $\mathrm{pH}[8,57]$. The rate is faster at lower $\mathrm{pH}$ and higher temperature. Three anammox bacterial species were cultured at different $\mathrm{pH}$ and temperatures in this study, which might cause variations in $\delta^{18} \mathrm{O}_{\mathrm{NO} 2}$ and $\delta^{18} \mathrm{O}_{\mathrm{NO} 3}$ values of MBR effluent and consequently the combined $\mathrm{O}$ isotope effects for $\mathrm{NO}_{2}{ }^{-}$oxidation $\left({ }^{18} \mathrm{E}_{\mathrm{NO} 2 \rightarrow \mathrm{NO} 3}\right)$ (Table S1).

\section{Application to ecological studies}

Although natural abundance $\mathrm{N}$ and $\mathrm{O}$ isotope ratios of nitrate $\left(\delta^{15} \mathrm{~N}_{\mathrm{NO} 3}\right.$ and $\left.\delta^{18} \mathrm{O}_{\mathrm{NO} 3}\right)$ have been used as an invaluable tool to identify the source and to determine the biogeochemical transformation processes [62], the isotope balances of oceanic $\mathrm{NO}_{3}{ }^{-}$are still poorly constrained at present. This is partly because $\mathrm{NO}_{3}{ }^{-}$can be produced during anammox (Fig. 1), which has been overlooked and led to divergent interpretation of $\delta^{15} \mathrm{~N}_{\mathrm{NO}}$ in freshwater and marine systems. Therefore, the contribution of anammox bacteria to $\mathrm{NO}_{2}{ }^{-}$reoxidation to $\mathrm{NO}_{3}{ }^{-}$(recycling $\mathrm{N}$ ) in the environments is currently one of the most prominent research topics.

A numerical $\mathrm{NO}_{3}{ }^{-}$isotope dynamics model was developed to evaluate the relative contribution of anammox to $\mathrm{NO}_{3}{ }^{-}$production in the marine and freshwater systems [26]. In this model, since $\mathrm{O}$ isotope effect of $\mathrm{NO}_{2}^{-}$oxidation to $\mathrm{NO}^{3-}\left({ }^{18} \varepsilon_{\mathrm{NO} 2-\rightarrow \mathrm{NO} 3-}\right)$ by anammox bacteria was not available, the ${ }^{18} \varepsilon_{\mathrm{NO} 2 \rightarrow \mathrm{NO} 3}$ - values of NOB (-7.0\% to
$-3.0 \%$ o) were used instead. According to this model, the inverse $\mathrm{N}$ and $\mathrm{O}$ isotope effects significantly influence the $\delta^{15} \mathrm{~N}$ and $\delta^{18} \mathrm{O}$ of produced $\mathrm{NO}_{3}{ }^{-}$and consequently the corresponding $\Delta \delta^{18} \mathrm{O}: \Delta \delta^{15} \mathrm{~N}$ trajectories. More negative (i.e., lower) ${ }^{15} \varepsilon_{\mathrm{NO} 2 \rightarrow \mathrm{NO} 3-}$ value pushes up $\delta^{15} \mathrm{~N}_{\mathrm{NO} 3}$ - value, thereby lowering the $\Delta \delta^{18} \mathrm{O}: \Delta \delta^{15} \mathrm{~N}$ trajectories. In contrast, more negative ${ }^{18} \varepsilon_{\mathrm{NO} 2 \rightarrow \mathrm{NO} 3-}$ value pushes up $\delta^{18} \mathrm{~N}_{\mathrm{NO} 3-}$ value, thereby lifting up the $\Delta \delta^{18} \mathrm{O}: \Delta \delta^{15} \mathrm{~N}$ trajectories. It should be noted that the lower ${ }^{18} \mathrm{E}_{\mathrm{NO} 2 \rightarrow \mathrm{NO} 3-}$ value (i.e., more negative) was yielded for a marine species " $\mathrm{Ca}$. $S$. japonica" than other two freshwater species (Fig. 3), suggesting that the higher $\Delta \delta^{18} \mathrm{O}: \Delta \delta^{15} \mathrm{~N}$ trajectories could be expected in marine systems than in freshwater systems. This can partly explain the widely observed $\Delta \delta^{18} \mathrm{O}: \Delta \delta^{15} \mathrm{~N}$ trajectories in freshwater systems $(<1)$ and in marine systems $(\geq 1)$.

Nitrite is an important branch compound between $\mathrm{N}$ loss by denitrification and anammox, and $\mathrm{N}$ retention by $\mathrm{NO}_{2}{ }^{-}$ reoxidation to $\mathrm{NO}_{3}{ }^{-}$. Natural abundance $\mathrm{N}$ and $\mathrm{O}$ isotopes of nitrite $\left(\delta^{15} \mathrm{~N}_{\mathrm{NO} 2}\right.$ and $\left.\delta^{18} \mathrm{O}_{\mathrm{NO} 2}\right)$ also provided an additional diagnostic to estimate the relative contribution of anammox to the $\mathrm{NO}_{3}{ }^{-}$pool [26]. Nitrite $\delta^{15} \mathrm{~N}$ and $\delta^{18} \mathrm{O}$ measurements have been used to evaluate what oxidative and reductive $\mathrm{NO}_{2}{ }^{-}$transformation processes are occurring and to what extent in ODZs [3].

Anammox bacteria in ODZs do not affiliate with the genus Scalindua, but with distinct clusters that are clearly separated from the sediment species [56]. Thus, dual $\mathrm{N}$ and $\mathrm{O}$ isotope effects of $\mathrm{NO}_{2}{ }^{-}$reoxidation should be further explored for other marine water and sediment anammox species for better model simulations for the oceanic $\mathrm{N}$ budget.

Acknowledgements This research was financially supported by Nagase Science and Technology Foundation and Institute for Fermentation, Osaka (IFO), which were granted to Satoshi Okabe, as well as JSPS KAKENHI (Grant number 18J20742), which was granted to Kanae Kobayashi. The present study was conducted using Joint Usage/Research Grant of Center for Ecological Research (2016jurccer24), Kyoto University.

\section{Compliance with ethical standards}

Conflict of interest The authors declare that they have no conflict of interest.

Publisher's note: Springer Nature remains neutral with regard to jurisdictional claims in published maps and institutional affiliations.

\section{References}

1. Brandes Ja, Devol AH. A global marine-fixed nitrogen isotopic budget: implications for Holocene nitrogen cycling. Glob Biogeochem Cycles. 2002;16:67-1-67-14.

2. Sigman DM, DiFiore PJ, Hain MP, Deutsch C, Wang Y, Karl $\mathrm{DM}$, et al. The dual isotopes of deep nitrate as a constraint on the 
cycle and budget of oceanic fixed nitrogen. Deep Res Part I. 2009;56:1419-39.

3. Casciotti KL. Nitrite isotopes as tracers of marine $\mathrm{N}$ cycle processes. Philos Trans R Soc A. 2016;374:20150295.

4. Casciotti KL, Sigman DM, Ward BB. Linking diversity and stable isotope fractionation in ammonia-oxidizing bacteria. Geomicrobiol J. 2003;20:335-53.

5. Casciotti KL, McIlvin M, Buchwald C. Oxygen isotopic exchange and fractionation during bacterial ammonia oxidation. Limnol Oceanogr. 2010;55:753-62.

6. Santoro AE, Casciotti KL. Enrichment and characterization of ammonia-oxidizing archaea from the open ocean: phylogeny, physiology and stable isotope fractionation. ISME J. 2011; 5:1796-808.

7. Buchwald C, Santoro AE, McIlvin MR, Casciotti KL. Oxygen isotopic composition of nitrate and nitrite produced by nitrifying cocultures and natural marine assemblages. Limnol Oceanogr. 2012;57:1361-75.

8. Nishizawa M, Sakai S, Konno U, Nakahara N, Takaki Y, Saito Y, et al. Nitrogen and oxygen isotope effects of ammonia oxidation by thermophilic Thaumarchaeota from a geothermal water stream. Appl Environ Microbiol. 2016;82:4492-504.

9. Casciotti KL. Inverse kinetic isotope fractionation during bacterial nitrite oxidation. Geochim Cosmochim Acta. 2009;73:2061-76.

10. Buchwald C, Casciotti KL. Oxygen isotopic fractionation and exchange during bacterial nitrite oxidation. Limnol Oceanogr. 2010;55:1064-74.

11. Martin TS, Casciotti KL. Nitrogen and oxygen isotopic fractionation during microbial nitrite reduction. Limnol Oceanogr. 2016;61:1134-43.

12. Granger J, Sigman DM. Nitrogen and oxygen isotope fractionation during dissimilatory nitrate reduction by denitrifying bacteria. Limnol Oceanogr. 2008;53:2533-45.

13. Kritee K, Sigman DM, Granger J, Ward BB, Jayakumar A, Deutsch C. Reduced isotope fractionation by denitrification under conditions relevant to the ocean. Geochim Cosmochim Acta. 2012;92:243-59.

14. Granger J, Sigman DM, Rohde MM, Maldonado MT, Tortell PD. $\mathrm{N}$ and $\mathrm{O}$ isotope effects during nitrate assimilation by unicellular prokaryotic and eukaryotic plankton cultures. Geochim Cosmochim Acta. 2010;74:1030-40.

15. Karsh KL, Granger J, Kritee K, Sigman DM. Eukaryotic assimilatory nitrate reductase fractionates $\mathrm{N}$ and $\mathrm{O}$ isotopes with a ratio near unity. Environ Sci Technol. 2012;46:5727-35.

16. Sigman DM, Granger J, DiFiore PJ, Lehmann MM, Ho R, Cane $\mathrm{G}$, et al. Coupled nitrogen and oxygen isotope measurements of nitrate along the eastern north pacific margin. Global Biogeochem Cycles. 2005;19:GB4022.

17. Casciotti KL, McIlvin MR. Isotopic analyses of nitrate and nitrite from reference mixtures and application to Eastern Tropical North Pacific waters. Mar Chem. 2007;107:184-201.

18. Buchwald C, Santoro AE, Stanley RHR, Casciotti KL. Nitrogen cycling in the secondary nitrite maximum of the eastern tropical North Pacific off Costa Rica. Global Biogeochem Cycles. 2015;29:2061-81.

19. Nunoura T, Takaki Y, Hirai M, Shimamura S, Makabe A, Koide $\mathrm{O}$, et al. Hadal biosphere: Insight into the microbial ecosystem in the deepest ocean on earth. Proc Natl Acad Sci USA. 2015;112: E1230-6.

20. Casciotti KL, Buchwald C, McIlvin M. Implications of nitrate and nitrite isotopic measurements for the mechanisms of nitrogen cycling in the Peru oxygen deficient zone. Deep Res Part I. 2013;80:78-93

21. Bourbonnais A, Altabet MA, Charoenpong CN, Larkum J, Hu H, Bange HW, et al. N-loss isotope effects in the Peru oxygen minimum zone studied using a mesoscale eddy as a natural tracer experiment. Glob Biogeochem Cycles. 2015;29:793-811.

22. $\mathrm{Hu} \mathrm{H}$, Bourbonnais A, Larkum J, Bange HW, Altabet MA Nitrogen cycling in shallow low-oxygen coastal waters off Peru from nitrite and nitrate nitrogen and oxygen isotopes. Biogeosciences. 2016;13:1453-68.

23. Codispoti LA. An oceanic fixed nitrogen sink exceeding $400 \mathrm{Tg} \mathrm{N}$ ${ }^{\mathrm{a}} 1 \mathrm{v}$ v the concept of homeostasis in the fixed-nitrogen inventory. Biogeosciences. 2007;4:233-53.

24. Gruber N, Galloway JN. An earth-system perspective of the global nitrogen cycle. Nature. 2008;451:293-6.

25. Kartal B, De Almeida NM, Maalcke WJ, Op den Camp HJM, Jetten MSM, Keltjens JT. How to make a living from anaerobic ammonium oxidation. FEMS Microbiol Rev. 2013; $37: 428-61$.

26. Granger J, Wankel SD. Isotopic overprinting of nitrification on denitrification as a ubiquitous and unifying feature of environmental nitrogen cycling. Proc Natl Acad Sci USA. 2016;113: E6391-E6400.

27. Babbin AR, Peters BD, Mordy CW, Widner B, Casciotti KL, Ward BB. Multiple metabolisms constrain the anaerobic nitrite budget in the Eastern Tropical South Pacific. Glob Biogeochem Cycles. 2017;31:258-71.

28. Kalvelage T, Lavik G, Lam P, Contreras S, Arteaga L, Löscher $\mathrm{CR}$, et al. Nitrogen cycling driven by organic matter export in the South Pacific oxygen minimum zone. Nat Geosci. 2013;6:228-34.

29. Kuypers MMM, Sliekers AO, Lavik G, Schmid M, Jorgensen BB, Kuenen JG, et al. Anaerobic ammonium oxidation by anammox bacteria in the Black Sea. Nature. 2003;422:608-11.

30. Kuypers MMM, Lavik G, Woebken D, Schmid M, Fuchs BM, Amann $\mathrm{R}$, et al. Massive nitrogen loss from the Benguela upwelling system through anaerobic ammonium oxidation. Proc Natl Acad Sci USA. 2005;102:6478-83.

31. Thamdrup B, Jensen MM, Ulloa O, Farı L, Escribano R. Anaerobic ammonium oxidation in the oxygen-deficient waters off northern Chile. Limnol Ocean. 2006;51:2145-56.

32. Brunner B, Contreras S, Lehmann MF, Matantseva O, Rollog M, Kalvelage T, et al. Nitrogen isotope effects induced by anammox bacteria. Proc Natl Acad Sci USA. 2013;110:18994-9.

33. Strous M, Fuerst Ja, Kramer EH, Logemann S, Muyzer G, van de Pas-Schoonen KT, et al. Missing lithotroph identified as new planctomycete. Nature. 1999;400:446-9.

34. Schmid M, Twachtmann U, Klein M, Strous M, Juretschko S, Jetten M, et al. Molecular evidence for genus level diversity of bacteria capable of catalyzing anaerobic ammonium oxidation. Syst Appl Microbiol. 2000;23:93-106.

35. Schmid M, Walsh K, Webb R, Rijpstra WI, van de Pas-Schoonen $\mathrm{K}$, Verbruggen MJ, et al. Candidatus "Scalindua brodae", sp. nov., Candidatus "Scalindua wagneri", sp. nov., Two new species of anaerobic ammonium oxidizing bacteria. Syst Appl Microbiol. 2003;26:529-38

36. Kartal B, Rattray J, van Niftrik LA, van de Vossenberg J, Schmid MC, Webb RI, et al. Candidatus 'Anammoxoglobus propionicus' a new propionate oxidizing species of anaerobic ammonium oxidizing bacteria. Syst Appl Microbiol. 2007;30:39-49.

37. Quan ZX, Rhee SK, Zuo JE, Yang Y, Bae JW, Park JR, et al. Diversity of ammonium-oxidizing bacteria in a granular sludge anaerobic ammonium-oxidizing (anammox) reactor. Environ Microbiol. 2008;10:3130-9.

38. Awata T, Oshiki M, Kindaichi T, Ozaki N, Ohashi A, Okabe S. Physiological characterization of an anaerobic ammoniumoxidizing bacterium belonging to the 'Candidatus scalindua' group. Appl Environ Microbiol. 2013;79:4145-8.

39. Oshiki M, Satoh H, Okabe S. Ecology and physiology of anaerobic ammonium oxidizing (anammox) bacteria. Environ Microbiol. 2016;18:2784-96. 
40. Ali M, Oshiki M, Awata T, Isobe K, Kimura Z, Yoshikawa H, et al. Physiological characterization of anaerobic ammonium oxidizing bacterium 'Candidatus Jettenia caeni'. Environ Microbiol. 2015;17:2172-89.

41. Oshiki M, Awata T, Kindaichi T, Satoh H, Okabe S. Cultivation of planktonic anaerobic ammonium oxidation (anammox) bacteria using membrane bioreactor. Microbes Environ. 2013;28:436-43.

42. (APHA) APHA, (AWWA) AWWA, (WEF) WEF. Standard methods for the examination of water and wastewater. 2012.

43. Sigman DM, Altabet Ma, Michener R, McCorkle DC, Fry B, Holmes RM. Natural abundance-level measurements of the nitrogen isotopic composition of oceanic nitrate: an adaption of the ammonia diffusion method. Mar Chem. 1997;57:227-42.

44. Holmes RM, McClelland JW, Sigman DM, Fry B, Peterson BJ. Measuring ${ }^{15} \mathrm{~N}^{-\mathrm{NH}_{4}}$ in marine, estuarine, and freshwaters: an adaptation of the ammonia diffusion method for samples with low ammonium concentrations. MarChem. 1998;60:235-43.

45. McIlvin MR, Altabet MA. Chemical conversion of nitrate and nitrite to nitrous oxide for nitrogen and oxygen isotopic analysis in freshwater and seawater. Anal Chem. 2005;77:5589-95.

46. Casciotti KL, Bohlke JK, McIlvin MR, Mroczkowski SJ, Hannon JE. Oxygen isotopes in nitrite: analysis, calibration, and equilibration. Anal Chem. 2007;79:2427-36.

47. Casciotti KL, Sigman DM, Hastings MG, Bohlke JK, Hilkert A. Measurement of the oxygen isotopic composition of nitrate seawater and freshwater using the dentirifier method. Anal Chem. 2002;74:4905-12.

48. Sigman DM, Casciotti KL, Andreani M, Barford C, Galanter M, Bhlke JK, et al. A bacterial method for the nitrogen isotopic analysis of nitrate in seawater and freshwater. Anal Chem. 2001;73:4145-53.

49. Lotti T, Kleerebezem R, Lubello C, van Loosdrecht MCM. Physiological and kinetic characterization of a suspended cell anammox culture. Water Res. 2014;60:1-14.

50. Fry B. Stable isotope ecology. New York, NY 10013, USA: Springer Science+Business Media, LLC; 2006.

51. Oshiki M, Ali M, Shinyako-Hata K, Satoh H, Okabe S. Hydroxylamine-dependent anaerobic ammonium oxidation (anammox) by 'Candidatus Brocadia sinica'. Environ Microbiol. 2016;18:3133-43.
52. Oshiki M, Mizuto K, Kimura ZI, Kindaichi T, Satoh H, Okabe $\mathrm{S}$. Genetic diversity of marine anaerobic ammonium-oxidizing bacteria as revealed by genomic and proteomic analyses of 'Candidatus Scalindua japonica'. Environ Microbiol Rep. 2017;9:550-61.

53. Strous M, Pelletier E, Mangenot S, Rattei T, Lehner A, Taylor MW, et al. Deciphering the evolution and metabolism of an anammox bacterium from a community genome. Nature. 2006;440:790-94.

54. Kartal B, Keltjens JT. Anammox biochemistry: a tale of heme c proteins. Trends Biochem Sci. 2016;41:998-1011.

55. Maalcke WJ, Reimann J, De Vries S, Butt JN, Dietl A, Kip N, et al. Characterization of anammox hydrazine dehydrogenase, a key-producing enzyme in the global nitrogen cycle. J Biol Chem. 2016;291:17077-92.

56. Ganesh S, Bertagnolli AD, Bristow LA, Padilla CC, Blackwood $\mathrm{N}$, Aldunate $\mathrm{M}$, et al. Single cell genomic and transcriptomic evidence for the use of alternative nitrogen substrates by anammox bacteria. ISME J 2018;12:2706-22.

57. Buchwald C, Casciotti KL. Isotopic ratios of nitrite as tracers of the sources and age of oceanic nitrite. Nat Geosci. 2013;6:308-13.

58. Kartal B, Kuypers MMM, Lavik G, Schalk J, Op Den Camp HJM, Jetten MSM, et al. Anammox bacteria disguised as denitrifiers: nitrate reduction to dinitrogen gas via nitrite and ammonium. Environ Microbiol. 2007;9:635-42.

59. Oshiki M, Ishii S, Yoshida K, Fujii N, Ishiguro M, Satoh H, et al. Nitrate-dependent ferrous iron oxidation by anaerobic ammonium oxidation (anammox) bacteria. Appl Environ Microbiol. 2013;79:4087-93.

60. Holler T, Wegener G, Niemann H, Ferdelman TG, Boetius A, Kristiansen TZ, et al. Correction for Holler et al., Carbon and sulfur back flux during anaerobic microbial oxidation of methane and coupled sulfate reduction. Proc Natl Acad Sci USA. 2012;109:21170-3.

61. Kumar S, Nicholas DJD, Williams EH. Definitive ${ }^{15} \mathrm{~N}$ NMR evidence that water serves as a source of ' $\mathrm{O}$ ' during nitrite oxidation by Nitrobacter agilis. FEBS Lett. 1983;152:71-4.

62. Kendall C, Elliott EM, Wankel SD. Tracing anthropogenic inputs of nitrogen to ecosystems. In: Michener R, Lajtha K, editors Stable isotopes in ecology and environmental science. 2nd ed. Blackwell Publishing Ltd: Malden; 2007. p. 375-449. 